\title{
Scholars and Literati at the University of Aix (1409-1793)
}

\author{
David de la Croix \\ IRES/LIDAM, UCLouvain
}

\author{
Alice Fabre \\ AMSE, Marseille
}

This note is a summary description of the set of scholars and literati who taught at the University of Aix (France) from its inception in 1409 to its abolishment during the French Revolution in 1793.

\section{The UNIVERSITY}

The University of Aix was founded in 1409 by the Count of Provence, who wanted to have a university on his lands, Avignon having been sold to the pope in 1348, to train the youth of the county, who otherwise had to study in Italy, or in the neighboring universities of Montpellier (1289) and Avignon (1303). The creation of the University of Aix was formalized by a Papal bull, and it enjoyed the same privileges as the universities of Paris (1200) and Toulouse (1229). It was heir to the old schools of grammar and law, as noted by Rashdall (1895). After difficult beginnings in the 15th century, it experienced a golden age in the 17 th century, and managed to maintain a certain notoriety in the 18 th century as shown in De la Croix and Fabre (2019). It did not teach arts, which were taught at the Royal Bourbon College, directed from 1621 to 1763 by the Jesuits (De la Croix and Fabre 2021a). It helped to train local notables in law, and it experienced a certain development in medicine. It should be noted that it was relatively spared by the wars of religion unlike neighboring universities, such as Valence for example (De la Croix and Fabre (2021b)).

\section{SOURCES}

There are no prosopographic catalogues of the University of Aix, and a large part of the archives were destroyed (in the 15th century by a fire linked to the war with Charles V, in the 18th century during the French Revolution, and also due to neglect in archiving). However, it is possible to reconstitute the academic staff on the basis of works carried out by historians, using the documents that remain (chronicles, notarial documents, statutes, etc.). Coulet (2012), Chavernac (1889), Belin (1905), and Fleury and Dumas (1929) provide many valuable insights. Additional bibliographical information is available in the biographical dictionary of the department written by Paul Masson (1931). For law professors, useful information can be found in the dictionary of famous jurists of Arabeyre, Halpérin, and Krynen (2007), in two books listing the notables and jurists of the Court of Provence (Cortez and des Clapiers-collongues (1931) and de Clapiers-Collongues (1904)), as well as in the anthology written for the 600th anniversary of the university (Collective 2009).

\section{SOME STATISTICS}

Table 1 shows some descriptive statistics. There are 365 scholars and literati. The column on the number of observations has two particularities. First, before the official creation of the university, a significant number of professors (in law, arts, and theology) taught in the city's colleges. Second, there is a gap in the data for the period 1450-1526 due to missing archives.

The year of birth is known for $26.8 \%$ of them. The mean age at nomination is 41.7 years. Longevity (mean age at death \& expected age at death when 30 ) is relatively high (with the exception of the early 15th century, when a lack of observation limits our ability to interpret the data) in particular during the last period. The birth place is known for only $38.6 \%$ of the individuals. The 
median distance between birth and Aix is $57 \mathrm{kms}$. This low number reflects the high percentage of regional professors, especially in law. Theologians were much more mobile. Abstracting from the number for the period 1450-1526 (based on 2 observations), the median distance has a tendency to decrease over time. Finally, $14.2 \%$ of the scholars have a Wikipedia page (in some language), and $19.2 \%$ of them have left a footprint in the catalogues of the libraries of the world, Worldcat, either by having published some work, or by having been the subject of published books and articles. These two percentages are to be seen as the upper bound, as the database is probably missing some of the obscure teachers of the University of Aix.

\begin{tabular}{|c|c|c|c|c|c|c|}
\hline \multicolumn{2}{|c|}{ Period } & \multirow{2}{*}{$\begin{array}{l}\text { nb. } \\
\text { obs }\end{array}$} & \multirow{2}{*}{$\begin{array}{l}\text { \% birth year } \\
\text { known }\end{array}$} & \multirow{2}{*}{$\begin{array}{l}\text { mean age } \\
\text { at nomin. }\end{array}$} & \multirow{2}{*}{$\begin{array}{l}\text { mean age } \\
\text { at death }\end{array}$} & \multirow{2}{*}{$\begin{array}{l}\text { exp. age } \\
\text { at death }\end{array}$} \\
\hline Start & End & & & & & \\
\hline 1200 & 1347 & 26 & 19.2 & 37.5 & 72.4 & 69.8 \\
\hline 1348 & 1449 & 43 & 9.3 & 37 & 53.8 & 61 \\
\hline 1450 & 1526 & 11 & 18.2 & 46 & 71 & 41 \\
\hline 1527 & 1617 & 71 & 19.7 & 33.7 & 65.2 & 65.7 \\
\hline 1618 & 1685 & 68 & 27.9 & 43.2 & 71.9 & 70.8 \\
\hline 1686 & 1733 & 58 & 37.9 & 47.6 & 74.7 & 71.4 \\
\hline 1734 & 1800 & 88 & 36.4 & 41.3 & 72.9 & 74.3 \\
\hline \multirow[t]{2}{*}{1200} & 1800 & 365 & $\overline{2} \overline{6} . \overline{8}$ & 41.7 & $\overline{7} \overline{1.1}$ & 70.4 \\
\hline & & & $\begin{array}{l}\% \text { birth place } \\
\text { known }\end{array}$ & $\begin{array}{l}\text { median distance } \\
\text { birth-institution }\end{array}$ & $\begin{array}{c}\% \text { with } \\
\text { Wikipedia }\end{array}$ & $\begin{array}{c}\% \text { with } \\
\text { Worldcat }\end{array}$ \\
\hline 1200 & 1347 & & 34.6 & 94 & 15.4 & 19.2 \\
\hline 1348 & 1449 & & 53.5 & 93 & 9.3 & 9.3 \\
\hline 1450 & 1526 & & 54.5 & 449 & 45.5 & 0 \\
\hline 1527 & 1617 & & 35.2 & 72 & 15.5 & 14.1 \\
\hline 1618 & 1685 & & 32.4 & 0 & 10.3 & 22.1 \\
\hline 1686 & 1733 & & 41.4 & 45 & 20.7 & 31 \\
\hline 1734 & 1800 & & 36.4 & 0 & 10.2 & 22.7 \\
\hline 1000 & 1800 & & $38 . \overline{6}$ & 57 & $14 . \overline{2}$ & 19.7 \\
\hline
\end{tabular}

Table 1: Summary statistics by period

\section{FIELDS}

Figure 1 shows the relative importance of fields, broadly defined. The development of law is one of the specificities of Aix, along with theology in the early periods, even before the creation of the university in 1409 . From the 17th century onwards, medicine, particularly its botanical branch, became more prominent, with a few renowned doctors, who were often called to Paris by the kings of France. Schools of surgery in Aix, but also in the nearby city of Marseilles, took off in the 18th century. It should be noted that the Faculty of Arts was mainly developed outside the walls, in the Jesuit College (1621-1763) named "Royal Bourbon College". Nevertheless, the weak place of the arts at the University of Aix seems to correspond to a particularity of southern French universities, as noted by Noël Coulet, the arts being more present in northern French universities. Even if Aix remained a medium-sized university, it experienced a golden age in the 17th century, and a less important decline than sometimes emphasized in the 18th century, thanks in particular to medicine (in Aix and in Marseilles) and botany. 


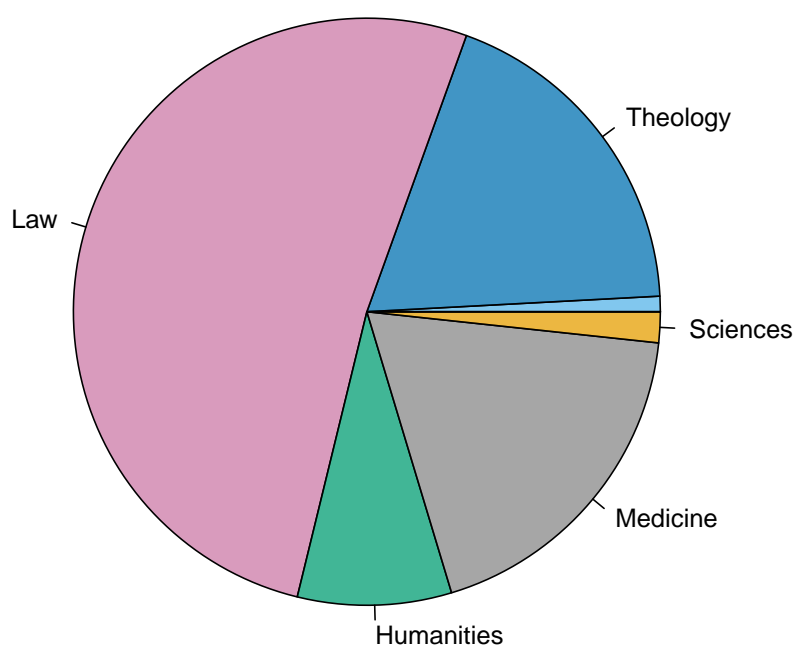

Figure 1: Broad fields at the University of Aix

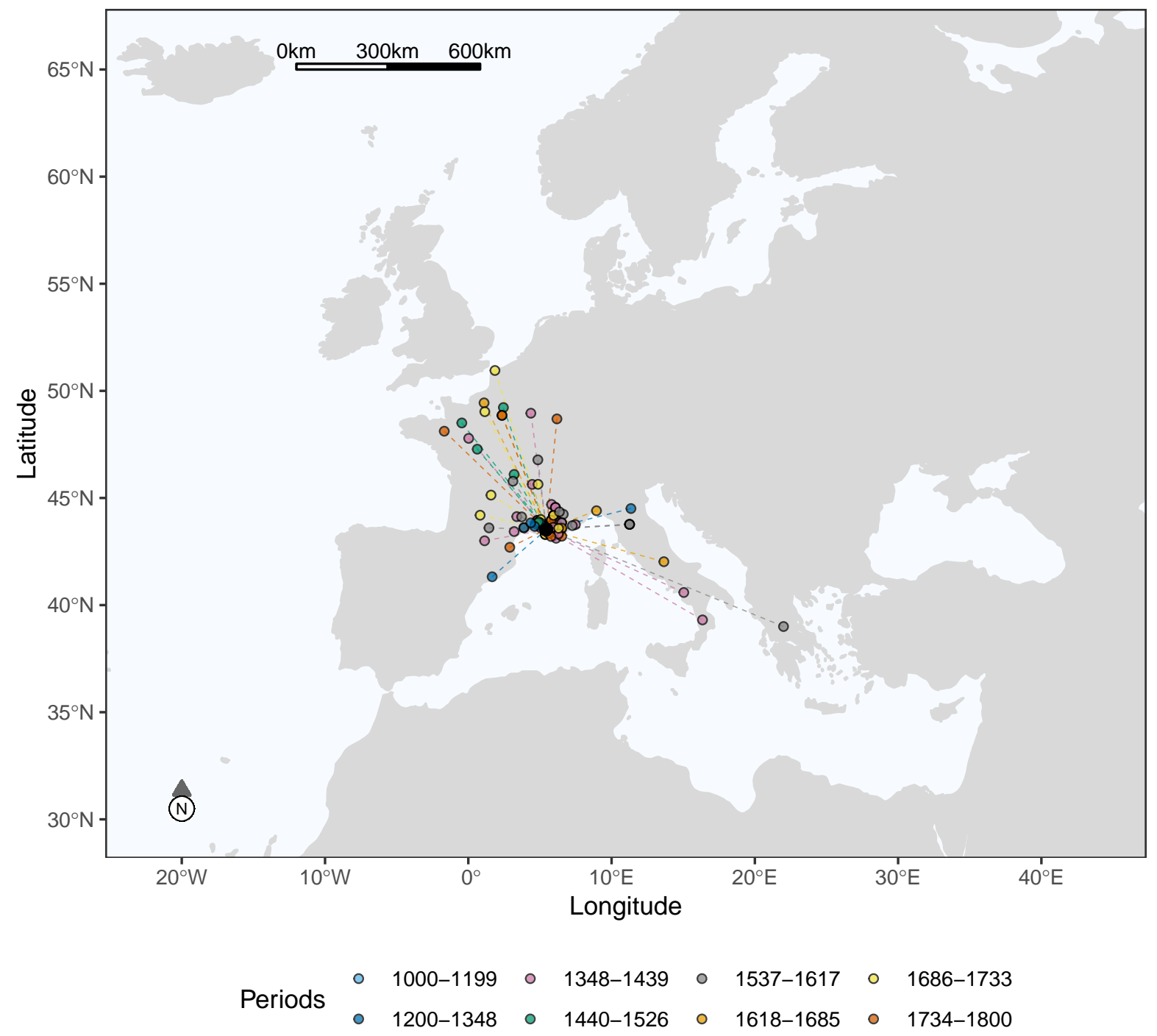

Figure 2: Place of birth of the scholars and literati at the University of Aix 
Remark: from 1601 onwards, the university offered two types of positions, city professors, with comparable salaries in each discipline, and royal professors, chairs created by Henry IV when the Royal Bourbon College was established ((De la Croix and Fabre (2021a)). The royal professors, at first members of the new university, were soon attached to the former university of Aix (which is the subject of this note) for those in law, medicine, and theology. Their salaries varied according to whether they were recruited for a first or second royal chair, which gave rise to many disputes during recruitment.

\section{Places of Birth}

Figure 2 is a plot of the places of birth of all the scholars of the University of Aix. It illustrates the median distance between places of birth and Aix found in Table 1 . The recruitment was mostly local. Many professors came from Provence, or the Alps (like Gassendi for example). The university was not entirely local however, as some professors came from Italy, Catalonia, and the North of France.

\section{HUMAN CAPITAL OF SCHOLARS AND LITERATI}

For each person in the database, we compute a heuristic human capital index, identified by combining information from Worldcat and Wikipedia using principal component analysis. We also compute the notability of the university at each date by averaging the human capital of the scholars active at the University of Aix 25 years before that date. The details are given in the Appendix. Figure 3 shows the names of all the scholars with a positive human capital index. The orange line plots the notability of the university.

The notability of the university was very low until 1600; this is partly due to missing sources, but also to the slow start of the university. Then, in the 17th century, there was a golden age for a few decades, followed by a decline. The notability rose again in the 18th century, giving the impression that a revival was cut short by the Revolution in 1793 .

\section{TOP 5 PROFESSORS}

We now provide a brief overview of the five professors with the highest human capital index.

Pierre Gassendi (1592 Champtercier - 1655 Paris). A French scientist and philosopher, born near Digne, he received his doctorate in theology in 1614 in Avignon. Gassendi was ordained a priest in 1616 and taught philosophy, as royal professor, at the University of Aix from 1617 to 1623. There, he made detailed astronomical observations, declared himself a supporter of Copernicus, and entered into correspondence with Galileo. A good friend of Peiresc, he was one of the leading figures of the golden age of the University of Aix. After Peiresc's death, he left Aix, and divided his time between Digne, where he had been provost of the cathedral since 1626, and Paris, where he made friends with many scientists, and taught mathematics at the Royal College from 1645 to 1648 . His fame has traveled as far as the moon, where a crater bears his name.

Guillaume Durant (1230? Puimisson, near Béziers -1296). A law graduate from the University of Bologna, Durant was a famous medieval law professor, nicknamed the Speculator (in Latin) after his work Speculum judiciale ("Mirror of the Law"), and an ecclesiastic; he was, among other things, a professor of law in Modena and in Aix (before the creation of the university) according to Chavernac (1889), and the bishop of Mende. His legal writings were very influential in his time. 


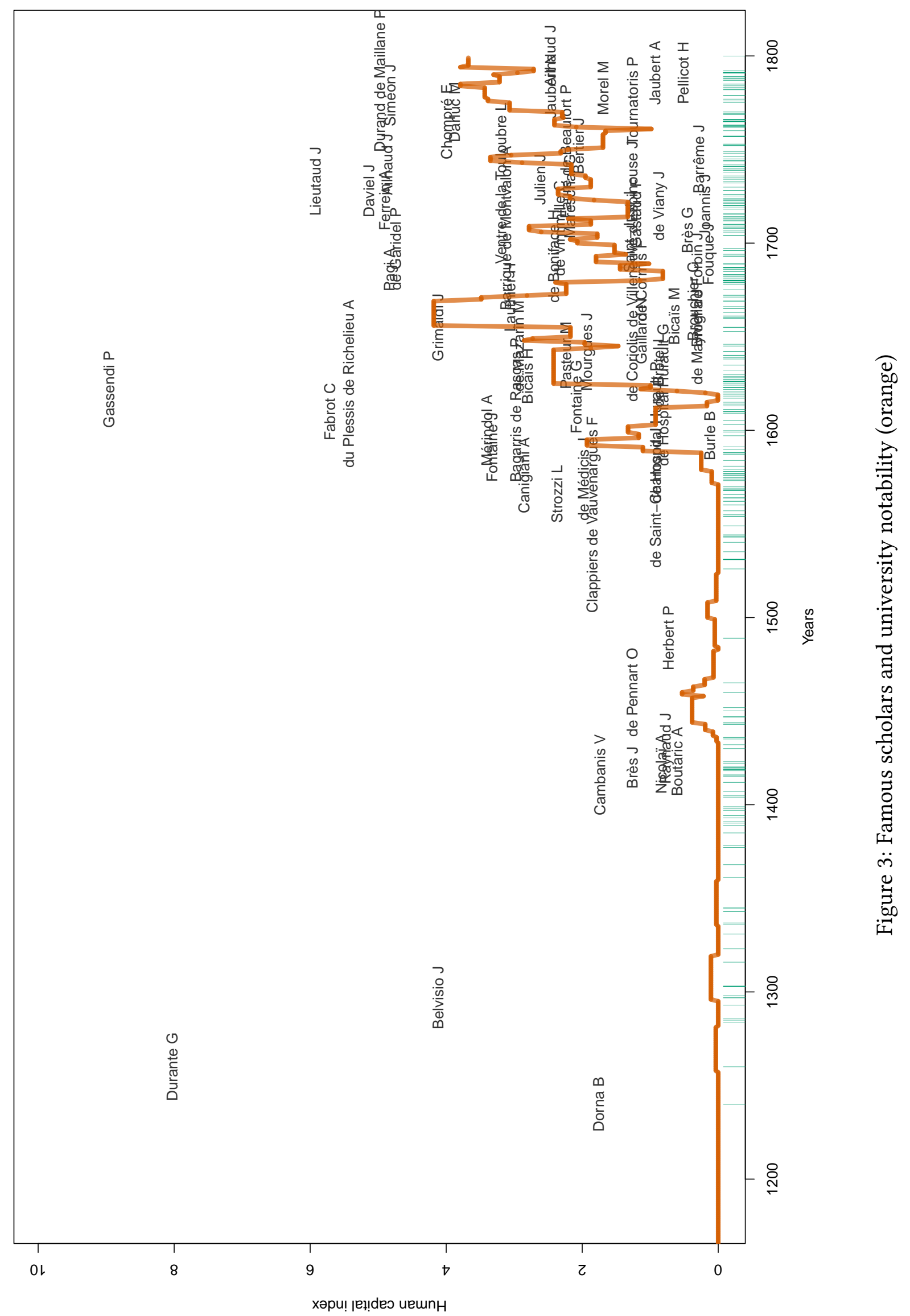


Joseph Lieutaud (1703 Aix-en-Provence - 1780 Versailles). Born into an old Aix family, his parents intended him for an ecclesiastical career, but he managed to persuade them to follow in the footsteps of his uncle P.-J. Garidel (a famous professor of botany at the University of Aix), and to study botany and medicine. He taught botany and medicine at Aix, while working as a doctor at the hospital in Aix. Through his clinical practice and the dissection of cadavers, he improved his knowledge of anatomy, a necessary condition, according to him, for any good medicine. It should be noted that some ecclesiastics tried to prevent him from performing dissections, but that by teaching one of his most fervent opponents geometry, he managed to make him an ally, and a regular at his public dissections (much appreciated by the people of Aix). He was called to the court of Louis XV in Versailles, and became a member of the Academy of Sciences. In 1774, during the smallpox epidemic that carried off King Louis XV, Joseph Lieutaud, who was in charge of the royal children, protected the future Louis XVI by inoculating him (a new procedure decried at the time in France), against the advice of many court doctors. He was a member of the Royal Society (astronomy section), and the president of the Paris Faculty of medicine. A street in Aix is named after him.

Charles Hannibal Fabrot (1580 Aix-en-Provence - 1659 Paris). He excelled at ancient languages, civil law, and canon law, and in 1602 he received a doctorate in law and became a lawyer at the Parliament of Aix. In 1609, he obtained a chair of law at the University of Aix. He was a good friend of Peiresc. He is best known for his translation of the Basilika, the code of the Eastern Empire until its fall, which was published in Paris in 1647. Fabrot edited unpublished works by Cujas, and the works of several Byzantine historians, and was also the author of various treatises on antiquity and law. A street in the center of Aix bears his name.

Jacques Daviel (1693 La Barre-en-Ouche - 1792 Geneva). After serving as an apprentice surgeon in Paris and as an assistant surgeon in the army, he volunteered in 1720 to help during the plague that ravaged Marseilles and its surroundings, seeing it as an opportunity to become a master of medicine. In 1722, he received a master's degree in surgery, and became a member of the Community of Surgeons of Marseilles. He became surgeon of the Hôtel-dieu of Marseille, then of the royal galleys, and practised as a general practitioner, performing numerous public dissections and giving anatomy courses. From 1735 onwards, he began to specialize in becoming an oculist, and innovated for the time by sending the results of his surgical operations to a journalist (Le Courrier d'Avignon, which gradually spread throughout the country), who for ten years published them in increasingly important and widely read articles, thus contributing to the surgeon's fame. Daviel became very famous, travelled extensively to spread his knowledge, and in 1741 invented in Marseilles a new and effective treatment for cataracts: the extraction of the crystalline lens. He was appointed oculist to the king.

\section{RELATED SCHOLARS}

Beyond those who taught at the University of Aix, several important individuals are related to the institution. They probably did not occupy a tenured teaching position, but they were involved in preaching, teaching and/or research, or there are strong assumptions that they were. Some of them were also archbishops of Aix, elected presidents of the university, in the organization of which they played a major role. Here, we show the three related scholars with the highest human capital index.

Nicolas Claude Fabri de Peiresc (1580 Belgentier (France) - 1637 Aix-en-Provence). His family was originally from Pisa and his father was a member of the Court of Accounts of Aix. He was born outside the city, during an episode of plague. He studied philosophy and law at Aix, Avignon, Padua, and Montpellier. From 1599 to 1601, he undertook a long trip to Italy. During this trip, he notably met the Pope and Galileo, and attended the marriage by proxy of Marie de Medici and the French king Henry IV. He was elected councilor at the Parliament 
of Aix in 1607, and continued to study and travel in Europe, and maintained an ongoing correspondence with some 500 contemporaries (Galileo, Gassendi, Kepler, Hevelius, Malherbe, Mersenne, Rubens, etc. ). He was a major figure of the Republic of Letters (res publica litteratorum), and a recognized universal spirit in his time. He was never a professor at the University of Aix, but was often consulted by the faculty (as his correspondence shows) and for example performed a public dissection at the University with his friend Gassendi in 1634, and organized events (observation of the eclipse of the moon at the top of the Sainte-Victoire, etc. ) in Aix. A collector, botanist, and astronomer (he discovered the Orion nebula in 1610, started a map of the moon, etc. ), he gave his name to a crater of the moon, which did not prevent his fame from fading away in the course of time, probably because he did not write any books, and because a large part of his letters were used by his direct descendant for her silkworm breeding.

Gilbert Génébrard (1537 Riom - 1597 Semur-en-Auxois). He was appointed archbishop of Aixen-Provence in 1591, which, because of the university's statutes, meant that he was elected president ("chancelier") of the university. A doctor of theology and a lecturer at the Royal College in 1569, he was very famous. His stay in Aix was nevertheless short-lived. Appointed in 1591, he did not take up his post until 1594, and fled the city when it surrendered to Henry IV. He was a member of the League (a Catholic movement opposed to Henry IV's accession to the throne). He was banished from the county in 1596 by the Parliament of Provence. During his stay in Aix, he was in favor of the Jesuits being called in to take over the old College of Arts, which they would do a few years later.

Jean-de-Dieu Raymond de Boisgelin de Cucé (1732 Rennes - 1804 Angervilliers). As archbishop of Aix-en-Provence (1770/1771-1801), he was the president of the University of Aix, and distinguished himself by his benevolence during a food shortage in 1772, obtaining the right to import wheat. He endowed Provence with a road network and began the construction of the Canal de Provence ( a waterway network). In 1776, he was elected member of the French Academy. In 1789, as a deputy of the clergy of Aix to the Estates General and then having been elected to the National Constituent Assembly (1789-1791) during the French Revolution, he voted for the abolition of privileges and the equal distribution of taxes, but defended the property rights of the clergy. A progressive and literary bishop, he became more conformist at the end of his career. He went into exile in England, and returned to France in 1801 under Napoleon Bonaparte, supported him, and became a cardinal and officer of the Legion of Honor.

\section{FAMILIES OF SCHOLARS}

We have identified a few cases of sons or grandsons of professors at the University of Aix who became professors in their turn at Aix. The percentage of professor sons with a professor father varies by field: $12 \%$ in medicine, $4 \%$ in law, and $0 \%$ in the other fields. These figures should be interpreted as lower limits to the true percentage. Among these families of scholars, we can distinguish for instance the de Broglia family, which provided professors of medicine to the University of Aix, as well as a line of notables and jurists at the Court of Aix. As indicated by Belin (1905), Jean-François De Broglia, trained in Italy, became a professor of medicine at the university in 1617, and his son Jean-Joseph succeeded him to a royal chair. They also both practised medicine outside the university. The son, Jean-Joseph, has 2 publications mentioned on Worldcat $(q=0.28)$, while his father has none (implying $q=0$ ).

\section{NeTWORK}

We assume that when a scholar occupied a position at more than one university over his/her life, this established a link between those universities. The universities with which Aix is linked are displayed in Figure 5. During the first periods, the University of Aix clearly belongs more to Southern Europe 


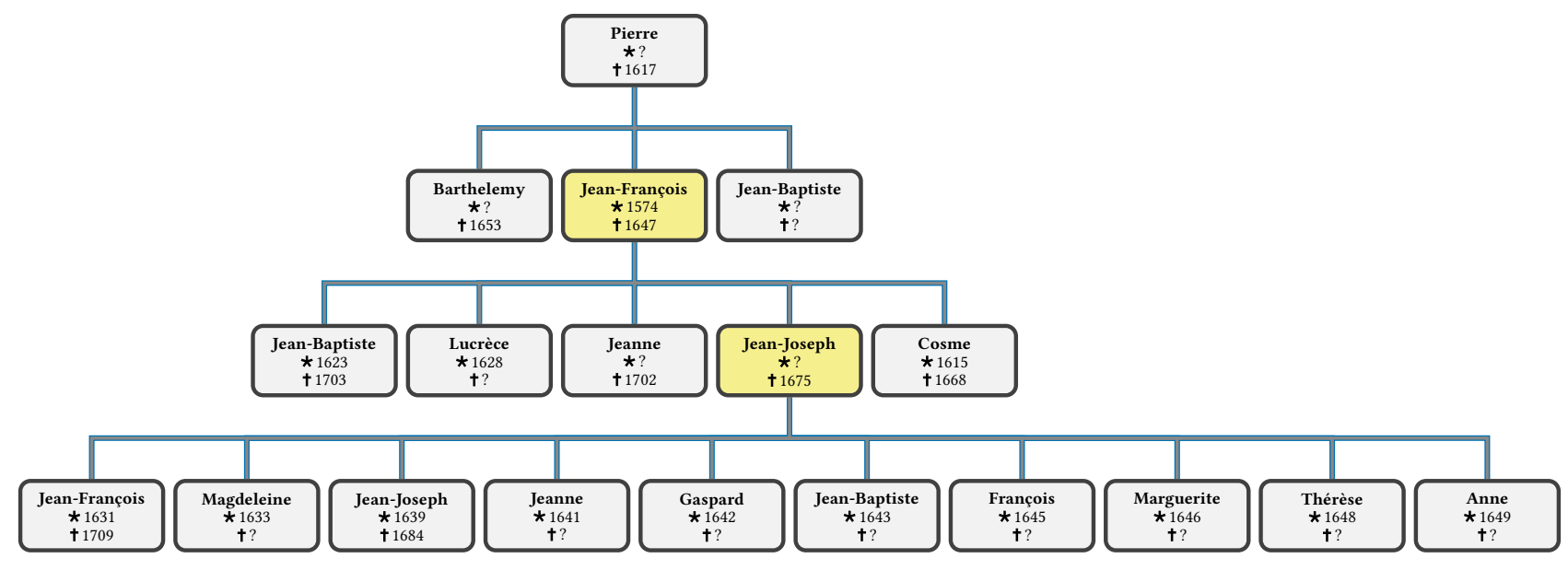

Figure 4: The de Broglia family. Professors at Aix in yellow squares

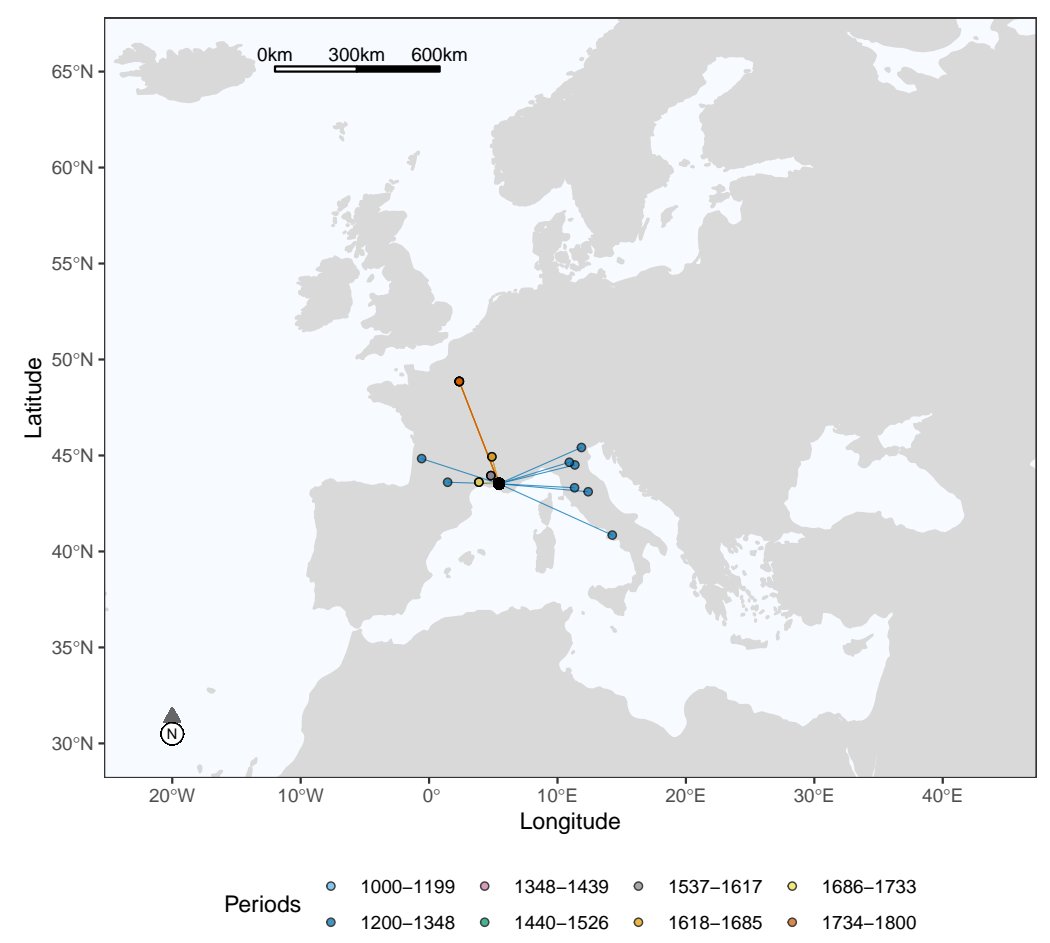

Figure 5: Aix University's Network of Institutions 
than to France. The Italian network is clearly marked in the first periods, before the creation of the university, or at its beginning, notably when Aix did not yet belong to the French crown (before 1486). Later, some professors from Aix (medicine, law, and theology) were also in Paris (such as Gassendi and Fabrot), but above all in other southern French universities (Toulouse, Montpellier, Avignon, and Valence).

\section{AnecDotes}

Medicine and botany had some successes in Aix. It was due to recognized botanists, whose works are still acclaimed today, such as Garidel, Michel Darluc, or to Joseph Lieutaud, a specialist in anatomy. However, it was also due to drugs that are no longer in fashion, like the famous "purgative powder" of Jean Gaspard d'Ailhaud: a soot-based "miracle remedy," which ensured his fortune and his ennoblement by the king in the 18th century, but is considered to be charlatanism today. Ailhaud's main idea was to reject bloodletting, which was recommended then for almost all diseases.

The Faculty of Law at Aix is also famous for its law students, like Mirabeau or Portalis, who made a name for themselves during the French Revolution, or under the First Empire (Napoléon). Mirabeau was elected from the "Tiers-Etat" (Third Estate) to the Estates General (1789) (a general assembly representing the French estates of the realm: the clergy (First Estate), the nobility (Second Estate), and the commoners (Third Estate); summoned by French king Louis XVI, the Estates General of 1789 ended when the Third Estate formed the National Assembly and, against the wishes of the king, invited the other two estates to join; this signaled the outbreak of the French Revolution); Portalis became one of the drafters of the Civil Code ("Code Napoléon", 1804), which grouped together the various French civil laws.

How do you fund a university? Ask the French king Henry IV. When the nobles of Aix asked the king to help them to finance their university, he did better: he created a rival university (the Royal Bourbon College), with royal chairs, financed by a new tax on salt. In the end, the royal chairs in law and medicine returned to the University of Aix, and most of the tax went directly into the king's coffers.

\section{APPENDIX}

The individual human capital index $q_{i}$ of an individual $i$ is given by:

$$
\begin{aligned}
q_{i}= & -1.76+0.43 \ln (\text { nb. characters of the longest Wikipedia page }) \\
& +0.40 \ln (\text { nb. Wikipedia pages in different languages })+0.47 \ln (\text { nb. works in Worldcat }) \\
& +0.46 \ln (\text { nb. publication languages in Worldcat })+0.47 \ln (\mathrm{nb} . \text { library holdings in Worldcat })
\end{aligned}
$$

We assume that having no Wikipedia page is similar to having one page with a length of 60 characters and that having no Worldcat page is similar to having a page with one work in one language held by one library. The constant -1.76 normalizes $q_{i}$ at 0 when there is neither a Wikipedia page, nor a Worldcat page. The weights $(0.43,0.40$, etc $)$ are obtained from the first principal component of the five indicators (De la Croix et al. 2020).

The notability $Q$ of a university aggregates the $q$ of the top 5 persons who were active in the preceding 25 years using the following formula:

$$
Q=\sqrt{\sum_{i=1}^{5} \frac{1}{5}\left(\frac{q_{i}}{s_{i}}\right)^{2}}
$$

where $s_{i}$ is the number of universities at which $i$ had an appointment. 


\section{ACKNOWLEDGMENTS}

This project has received funding from the European Research Council (ERC) under the European Union's Horizon 2020 research and innovation programme, under grant agreement No 883033 "Did elite human capital trigger the rise of the West? Insights from a new database of European scholars."

First version June 9, 2021. Updated December 20, 2021.

\section{REFERENCES}

Arabeyre, Patrick, Jean-Louis Halpérin, and Jacques Krynen. 2007. Dictionnaire historique des juristes français (XIIe-XXe siècle). Paris: Presses Universitaires de France.

Belin, Ferdinand. 1905. Histoire de l'ancienne université de Provence, ou Histoire de la fameuse univesité d'Aix: d'après les manuscrits et les documents originaux. Paris: A. Picard et fils.

Chavernac, Félix. 1889. Histoire de l'Université d'Aix. Premier fascicule, Revue Sextienne, Makaire.

Collective. 2009. Six siècles de droit à Aix: 1409-2009: mémorial de la Faculté de droit et de science politique d'Aix-Marseille à l'occasion du sixième centenaire de sa fondation. Presses universitaires d'Aix-Marseille.

Cortez, Fernand, and B des Clapiers-collongues. 1931. Les Grands Officiers Royaux de Provence au Moyen Age: listes chronologiques du haut personnel administratif, judiciaire \& financier. Secrétariat de la Société d'Etudes Provençales.

Coulet, Noël. 2012. "Le premier siècle de Université d'Aix." Provence Historique LXII, 248:159-170.

De la Croix, David, Frédéric Docquier, Alice Fabre, and Robert Stelter. 2020. "The Academic Market and the Rise of Universities in Medieval and Early Modern Europe (1000-1800).” CEPR Discussion Paper 14509.

De la Croix, David, and Alice Fabre. 2019. "A la découverte des professeurs de l'ancienne université d'Aix, de ses origines á 1793.” Annales du midi 131:379-402.

. 2021a. "Scholars and Literati at the Royal Bourbon College in Aix-en-Provence (16031763)." Repertorium eruditorum totius Europae 3:43-50.

- 2021b. "Scholars and Literati at the University of Valence (1452-1763)." Repertorium eruditorum totius Europae 2:13-20.

de Clapiers-Collongues, Balthasar. 1904. Chronologie des officiers des cours souveraines de Provence. Typographie et lithographie B. Niel.

Fleury, Georges, and Auguste Dumas. 1929. Histoire de l'ancienne Université d'Aix de 1730 à 1793: d'après des documents inédits. Nicollet.

Masson, Paul R. 1931. Les Bouches-du-Rhône: encyclopédie départementale, Dictionnaire biographique des origines à 1800. Marseille: Archives départementales des Bouches-du-Rhône.

Rashdall, Hastings. 1895. The Universities of Europe in the Middle Ages. Oxford: Clarendon Press. 